\title{
Handbook of Florida Water Regulation: Pollutant Storage Tank Systems ${ }^{1}$
}

Michael T. Olexa, Luke D'Isernia, Laura Minton, Dulcy Miller, and Sarah Corbett ${ }^{2}$

\section{Preface}

This handbook is designed to provide an accurate, current, and authoritative summary of the principle Federal and Florida laws that directly or indirectly relate to agriculture. This handbook should provide a basic overview of the many rights and responsibilities that farmers and farmland owners have under both Federal and Florida laws as well as the appropriate contact information to obtain more detailed information. However, the reader should be aware that because the laws, administrative rulings, and court decisions on which this handbook is based are subject to constant revision, portions of this publication could become outdated at anytime.

Several details of cited laws are also left out due to space limitations.

This handbook is distributed with the understanding that the authors are not engaged in rendering legal or other professional advice, and the information contained herein should not be regarded as a substitute for professional advice. This handbook is not all inclusive in providing information to achieve compliance with the Federal and Florida laws and regulations governing water protection. For these reasons, the use of these materials by any person constitutes an agreement to hold harmless the authors, the Florida Cooperative Extension Service, the Institute of Food and Agricultural Sciences, and the University of Florida for any liability claims, damages, or expenses that may be incurred by any person as a result of reference to or reliance on the information contained in this handbook.

\section{Who Regulates Pollultant Storage Tank Systems?}

Statewide regulation of stationary storage tanks is primarily the domain of the Florida Department of Environmental Protection (DEP). The DEP has the power to regulate pollutant storage tanks through the Florida Statutes, particularly Chapter 376,

"Pollutant Discharge Prevention and Removal". Consequently, most of the rules covered in this section are those of the DEP. It is important to note, however, that the regulations allow individual county governments to promulgate their own regulations.

1. This is EDIS document FE613, a publication of the Food and Resource Economics Department, Florida Cooperative Extension Service, Institute of Food and Agricultural Sciences, University of Florida, Gainesville, FL. Published December 2005. Please visit the EDIS website at http://edis.ifas.ufl.edu.

2. Michael T. Olexa, Professor, Food and Resource Economics Department, Florida Cooperative Extension Service, Institute of Food and Agricultural Sciences, University of Florida, Gainesville, FL; Director, Agricultural Law Center, University of Florida, Gainesville, FL; and Chair, Agricultural Law Committee of The Florida Bar. Luke D'Isernia, former student (graduated cum laude in 2005), Levin College of Law, University of Florida, Gainesville, FL. Laura Minton, Attorney, Dean, Mead, Egerton, Bloodworth, Capouano, and Bozarth, Orlando, FL. Dulcy Miller, attorney, Foley and Lardner, LLP, Orlando, FL. Sarah Corbett, Attorney, Florida Second District Court of Appeal, Lakeland, FL.

The Institute of Food and Agricultural Sciences (IFAS) is an Equal Opportunity Institution authorized to provide research, educational information and other services only to individuals and institutions that function with non-discrimination with respect to race, creed, color, religion, age, disability, sex, sexual orientation, marital status, national origin, political opinions or affiliations. U.S. Department of Agriculture, Cooperative Extension Service, University of Florida, IFAS, Florida A. \& M. University Cooperative Extension Program, and Boards of County Commissioners Cooperating. Larry Arrington, Dean 
These local regulations can be more stringent than those of the DEP. County authorities should be consulted even if the storage tank activity or condition is apparently within the statewide standards.

\section{What Is a Pollutant?}

A tank will fall within the scope of the regulations if it holds a pollutant. A "pollutant" is basically defined as follows:

- Any type of oil in any form

- Gasoline.

- Any pesticide.

- Any ammonia or chlorine compound or derivative, excluding liquid petroleum gas.

\section{Which Systems Are Regulated?}

The bulk of the regulations only apply to storage tank systems whose individual storage capacity is greater than 110 gallons. Smaller tanks only need to comply with the general requirements that they do not discharge their contents into the environment, and that they conform to fire prevention standards.

There is a list of 23 types of storage tank systems that are exempt from this chapter. Any agricultural storage tank system of 550 gallons or less capacity is exempt. For an updated list of exempt storage tank systems check with the DEP.

The DEP makes important distinctions between new tanks and those that were already in operation before 1992. New tanks are subject to the strictest safety standards, but existing tanks must be brought into compliance with many of the same standards for overfill protection, monitoring systems, and tank linings within a given period. The time allowed for this "retrofitting" varies depending upon the year the tank was installed, but the DEP contemplates the complete retrofitting of all existing tanks by 2009.

Aboveground systems are subject to less restrictive regulation and are subject to this chapter if they have a storage capacity greater than 550 gallons. (An "aboveground" tank has no more than 10 percent of its volume buried, including integral piping.) These tanks, however, are subject to similar record keeping rules as buried tanks and must be equipped with an impervious containment barrier to catch spills. Furthermore, any part of the tank in contact with the ground must be protected against corrosion.

\section{What Should System Owners Do?}

Other than federal, state, and local permits required for the physical construction and installation of storage tank systems, there are no permitting requirements stemming directly from the DEP or local tank regulation. However, system owners must do the following:

- Register tanks with the DEP 30 days before the start of the installation.

- Notify DEP 30 days before the closure of any storage tank system or 10 days before replacement or upgrading of a system occurs.

- Notify DEP within 30 days of a change in ownership of a storage tank system.

- Report immediately any spills that represent any threat to environmental quality (this includes discharges in excess of 100 gallons into pervious surfaces).

\section{What Are the Construction, Repair, and Testing Standards?}

All new tanks must comply with a comprehensive list of safety requirements, including double-wall or reinforced construction, monitoring systems (including monitoring wells), strike plates, electric isolation systems, and other such specifics. Similar requirements have been promulgated for the pipe systems used in connection to the tanks and corrosion protection is required.

The DEP also provides extensive requirements for testing the integrity of tanks, and for taking samples from tanks, monitoring wells, and soil in the vicinity of the tank. All testing must be performed by trained personnel. Although the testing intervals are specified in the rules, the DEP retains the authority to 
order complete system testing whenever it deems it necessary, based upon the following:

- The operator's failure to comply with rules.

- Evidence of a discharge or of contamination in the area.

Operators of storage facilities are required to keep records for DEP inspection. These records must include the results of all tests and inspections, as well as maintenance and inventory notes on the tanks or their contents. The records must date back at least two years and must be made available to the DEP within five working days' notice.

\section{What Are the Cleanup Safeguards and Procedures?}

Operators may be required, by both state and federal law, to adopt a Spill Prevention Control and Countermeasure Plan before installing a tank. This is pursuant to the federal policy of monitoring anyone with the potential to pollute the environment through petroleum discharge. This plan, or a DEP-approved alternative plan, should detail the drainage and other engineering measures taken to mitigate the damage of spills and may require an advance, written commitment of materials and manpower that will be used to clean up any spills that occur.

As noted earlier, spills must be reported immediately, and the owner or operator must take immediate steps to "contain, remove, or abate the discharge." If groundwater quality is threatened by the spill, the DEP may also order the owner to take whatever corrective action is necessary to reduce the hazard to the public.

\section{What Is the Proper Procedure for Tank Abandonment?}

The proper procedure for tank abandonment is as follows:

- Abandoned tanks must be pumped out and thoroughly cleaned of vapor.

- Underground tanks either must be removed from the ground, or must be filled with sand, concrete, or similar inert material.
- Tanks disposed as junk must be perforated or otherwise made unusable.

- Petroleum tanks that are intended for reuse must be clearly labeled as "not for food use."

- No abandoned tank may be used to store pollutants. Abandoned tanks may not be reused unless completely retrofitted to comply with the standards for new tanks.

Under the Comprehensive Environmental Response, Compensation, and Liability Act (CERCLA), landowners may be held liable for leakage from tanks that have been abandoned on their property by previous owners. Consequently, buyers should thoroughly inspect the property before purchase (see FE584, CERCLA). If leaking tanks are discovered, the clean up may be supervised by the landowner or by the EPA. It will inevitably be costly.

\section{Source}

Chapter 376, Florida Statutes, Sections 376.30 to 376.326; Title 62, Florida Administrative Code; 40 Code for Federal Regulations, Sections 280 and 281

\section{Contact Information}

Pollutant Storage Tank System Management (FE616, Contact Agencies)

- S-2, Florida Department of Environmental Protection

- L-4, Emergency Superfund Branch

- F-3, Emergency Planning and Community Right-to-Know

- F-4, TSCA Assistance Information Service

\section{Acknowledgments}

The authors are indebted to the personnel of both state and federal agencies who provided their time and advice in the preparation of this handbook. The authors are especially indebted to Richard Budell of the Office of Agricultural Water Policy of the Florida Department of Agriculture and Consumer Services for providing funds for the development of this publication. 